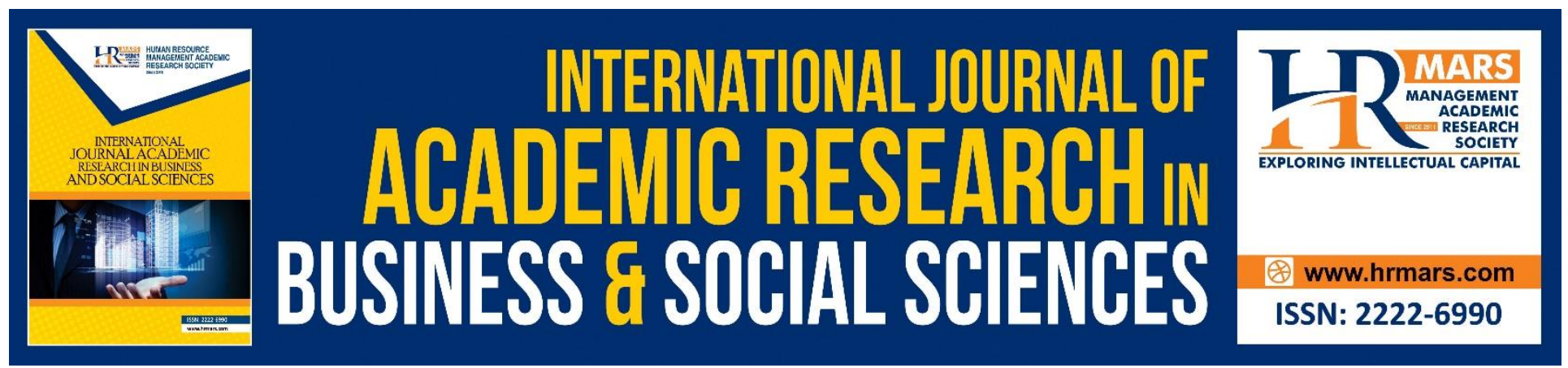

\title{
The Structure in Existing Shariah Principle of Islamic Home Financing: A Review
}

\section{Sharifah Arni Syed Jaaffar and Puspa Liza Ghazali}

To Link this Article: http://dx.doi.org/10.6007/IJARBSS/v8-i12/5231

DOI: $10.6007 /$ IJARBSS/v8-i12/5231

Received: 25 Nov 2018, Revised: 19 Dec 2018, Accepted: 26 Dec 2018

Published Online: 09 Jan 2018

In-Text Citation: (Jaaffar \& Ghazali, 2018)

To Cite this Article: Jaaffar, S. A. S., \& Ghazali, P. L. (2018). The Structure in Existing Shariah Principle of Islamic Home Financing: A Review. International Journal of Academic Research in Business and Social Sciences, 8(12), 1337-1344.

Copyright: (c) 2018 The Author(s)

Published by Human Resource Management Academic Research Society (www.hrmars.com)

This article is published under the Creative Commons Attribution (CC BY 4.0) license. Anyone may reproduce, distribute, translate and create derivative works of this article (for both commercial and non-commercial purposes), subject to full attribution to the original publication and authors. The full terms of this license may be seen at: http://creativecommons.org/licences/by/4.0/legalcode

Vol. 8, No. 12, 2018, Pg. 1337 - 1344

http://hrmars.com/index.php/pages/detail/IJARBSS

JOURNAL HOMEPAGE

Full Terms \& Conditions of access and use can be found at http://hrmars.com/index.php/pages/detail/publication-ethics 


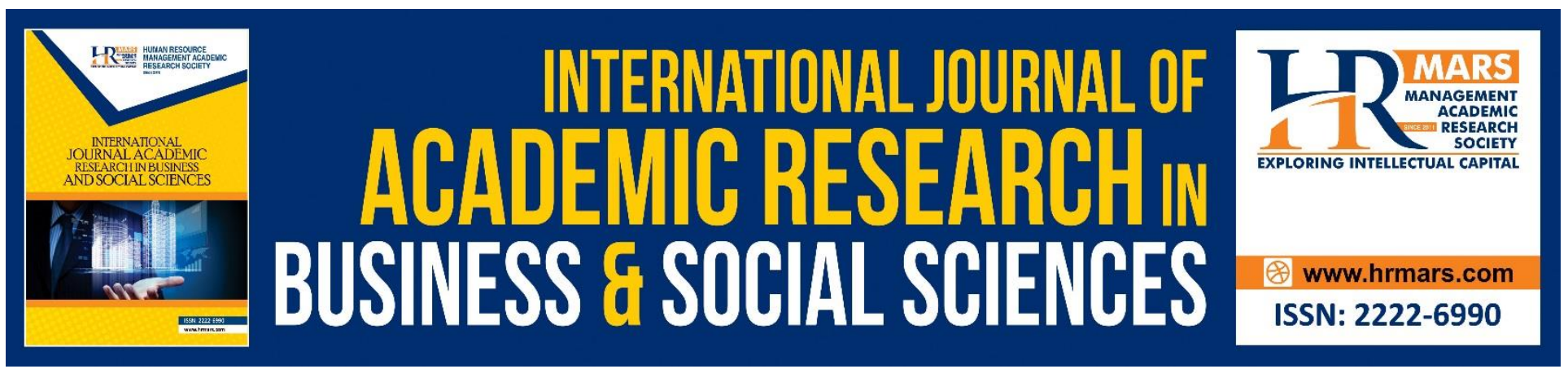

\title{
The Structure in Existing Shariah Principle of Islamic Home Financing: A Review
}

\author{
${ }^{1}$ Sharifah Arni Syed Jaaffar and ${ }^{2 *}$ Puspa Liza Ghazali \\ ${ }^{182}$ Faculty of Economic and Management Science, Universiti Sultan Zainal Abidin, \\ 21300 Kuala Nerus. Terengganu. Malaysia. \\ Corresponding Author's Email: puspaliza@unisza.edu.my
}

\begin{abstract}
Islamic finance has grown tremendously since it first emerged in 1970's. Malaysia's Islamic finance industry has been in existence for over 40 years. This research aims for knowing the structure in top three most applied in Islamic home financing which are Bai Bithaman Ajil, Musyarakah Mutanaqisah and Tawarruq. The structure for each syariah principles is different due to its dealing party. From the structure, borrower gets a clearer view of party that participates in buying a house.

Keywords: Syariah Principle, Islamic Home Financing, Bai Bithaman Ajil, Musyarakah Mutanaqisah and Tawarruq.
\end{abstract}

\section{INTRODUCTION}

Islamic home financing is a basic necessity nowadays as it complement the syariah in financing sector. Before the era of Islamic financing, conventional loan is the only choice that borrower can access to own the house. The basis of conventional home financing is in conflict with the principles of Islam, where riba (usury) and gharar (uncertainty) are integral part of the financing. Islamic banking entered Malaysia in the year 1983, and over the past 20 years, it has succeeded in developing a vibrant Islamic financial market.

Islamic banks in Malaysia offer a wide range of products, for instance from basic Shariah-compliant retail products to insurance, mortgages, investment instruments and large-scale project financing. On the large scale of Islamic banking activities, Malaysia offers various financial innovations that attract investors to cultivate their investment in Malaysia (Amin, 2008). This article focus on structures of 3 most top Shariah principles practiced for home financing in Malaysia. The top listed Shariah principles in Malaysia are Bai Bithaman Ajil (deferred payment sale), Musyarakah Mutanaqisah (diminishing partnership) and Tawarruq (direct instrument of debt creation). There are 16 Islamic Financial Institution (IFI) in Malaysia. Table 1 show the summary of IFI in Malaysia as at March 2016. 
INTERNATIONAL JOURNAL OF ACADEMIC RESEARCH IN BUSINESS AND SOCIAL SCIENCES Vol. 8, No. 12, Dec, 2018, E-ISSN: 2222-6990 C 2018 HRMARS

\begin{tabular}{|l|l|l|}
\hline Islamic Financial Institution & $\begin{array}{l}\text { Name of Home } \\
\text { Finance }\end{array}$ & Shariah Concept \\
\hline Affin Islamic Bank Berhad & Home Fin. -i & MM \\
\hline $\begin{array}{l}\text { Al Rajhi Banking \& Investment } \\
\text { Corporation Malaysia Bhd }\end{array}$ & Home Fin-i & BBA \\
\hline Alliance Islamic Bank Berhad & i-Wish Home Fin-i & BBA \\
\hline Am Islamic Bank Berhad & Home Fin-i & BBA \& MM \\
\hline Asian Finance Bank Berhad & Home Fin-I & MM \\
\hline Bank Islam Malaysia Berhad & Baiti Home Fin-i & Tawarruq \\
\hline Bank Muamalat Malaysia Berhad & Home Fin-i & MM \\
\hline Cimb Islamic Bank Berhad & Flexi Home Fin-i & Tawarruq \\
\hline HSBC Amanah Malaysia Berhad & Home Smart-i & MM \\
\hline Hong Leong Islamic Malaysia Berhad & Flexi Prop Fin-i & Tawarruq \\
\hline $\begin{array}{l}\text { Kuwait Finance House (Malaysia) } \\
\text { Berhad }\end{array}$ & MM home Fin-i & ljarah Muntahiah \\
\hline Maybank Islamic Berhad & $\begin{array}{l}\text { Home Equity \& } \\
\text { Maxi Home }\end{array}$ & MM \& Tawarruq \\
\hline OCBC Al Amin Bank Berhad & Manarat Home-i & ljarah Muntahiah \\
& Bi Tamlik \\
\hline Public Islamic Bank Berhad & EqBA Home Fin-i & Bai Al Inah \\
\hline RHB Islamic Bank Berhad & $\begin{array}{l}\text { Saadiq My Home- } \\
\text { i }\end{array}$ & MM \\
\hline Standard Chartered Saadiq Berhad & MM \\
\hline
\end{tabular}

Table 1: Summary of Islamic Home Financing in Malaysia

\section{LITERATURE REVIEW}

\section{Bay Bithaman Ajil (BBA)}

This principle is an alternative of conventional housing loan offered by most conventional banks as it's said to be free from riba, gharar or maisir. Bay Bithaman Ajil means a deferred payment sale or basically a trading transaction that is used for property, vehicle or other consumer goods. It is a mode of Islamic financing used for property, vehicle, as well as financing of other consumer goods. Almost every Islamic bank in early establishment of Islamic financing practices it. 


\section{Criteria of Bai Bithaman Ajil}

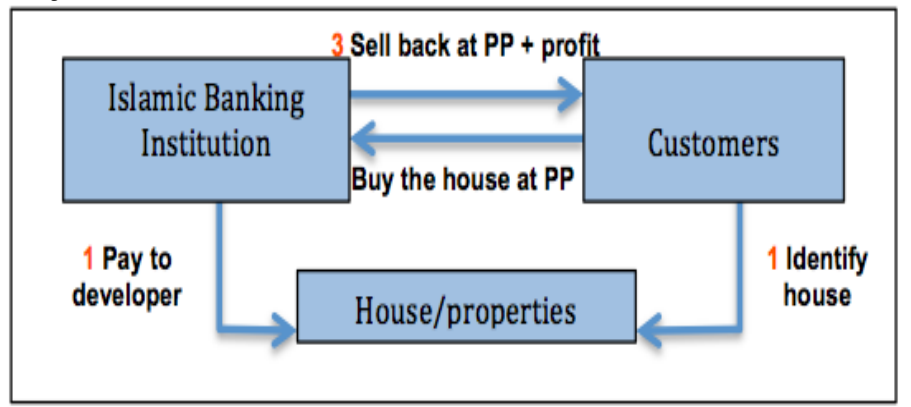

Figure 1: The structure of Bai Bithaman Ajil (BBA) house financing.

The underlying transactions of the BBA are based on the concept Murabahah (cost plus) whereby the sales price is added up with the profit. Technically, this financing facility is based on the activities of buying and selling. Using this contract, the Islamic bank may finance the customer who wishes to acquire a given asset but to defer the payment of the asset for a specific period or to pay by installment. The asset that the customer wish to purchase for example, are bought by the bank and sold to customer at an agreed price as in Figure 1.

An agreed price will include the bank's mark-up profit. Once the bank and customer determine the tenure, the manner of the installments will then be concluded. The customer is also allowed to settle payment within a pre-agreed period in a lump sum. The price at which the bank sells the property will include the actual cost of the asset and will also incorporate the bank's profit margin. There is no interest charged and the extra price compensates the bank for its profit. Installments remain fixed over the period of the contract and no adjustment is made if interest rates fluctuate. The fixed monthly installments are determined by the selling price, repayment period and the percentage margin of financing.

\section{Musyarakah Mutanaqisah (MM)}

Musyarakah Mutanaqisah (MM or Dimininshing Partnership is still new in the market but it started to be famous in the islamic finance Malaysia's market. It can be implement for various financing purposes including: housing projects, car financing, financing of working materials and equipment, financing business project and etc.

\section{Criteria Musyarakah Mutanaqisah (MM)}

MM was a hybrid product in home financing that consist three contracts: musharakah (partnership), ljarah (leasing) and Bai (Sale). Basic steps involves in the MM home financing structure included: First Stage, which is the customer identifies the property that $s /$ he wants to purchase and $s /$ he approaches the bank for financing. The customer and the bank will enter into a MM arrangement where the purpose is to acquire a property. The initial down payment or deposit made by the customer will be his/her contribution towards the MM Venture while the bank's contribution will equal the financing amount.

On Second Stage, The bank subsequently leases the acquired property to the customer. The rental paid by the customer will be distributed among partners in accordance to the shareholding at the 
point the rental is paid/ received. In practice, the bank's portion of the rental income mirrors the interest rate charged by its conventional counterpart in the similar product offering.

While on last stage, throughout the lease tenure, based on agreed time intervals, the customer purchases the bank's equity of the jointly acquired property. Over the financing tenure, therefore, the bank's shares are redeemed and reduced by the purchase made by the customer as in Figure 2. At the end of the financing agreement, once the equity portion of the bank has been fully redeemed, the ownership title will eventually be transferred to the customer. The partnership is then effectively terminated.

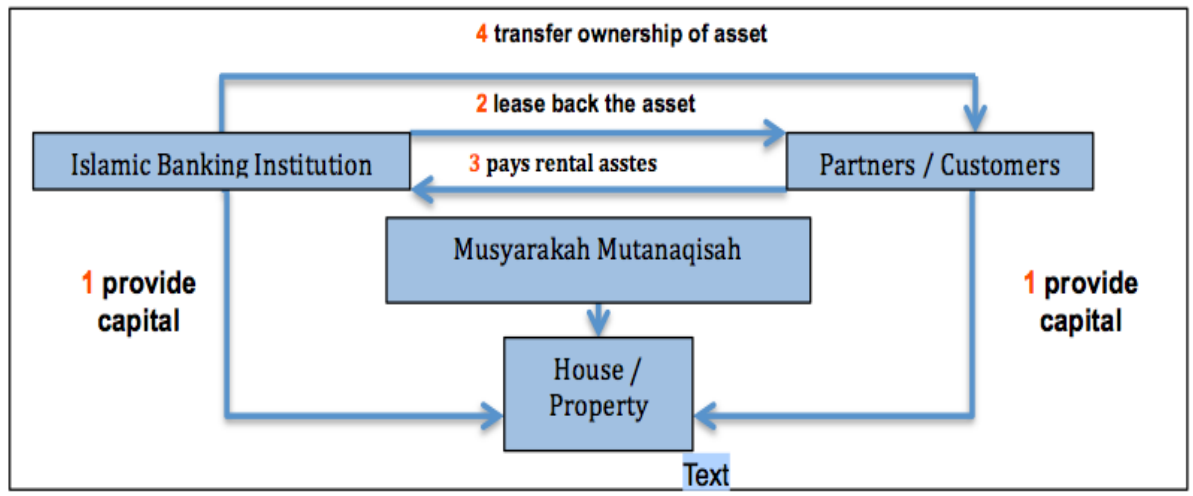

Figure 2: The structure of Musharakah Mutanaqisah (MM) house financing

Customer submits project proposal and applies for the financing approved, enters into a musharakah arrangement with customer either leases bank's shares in the project or shares the profit and loss with bank. Customer will use his portion from the lease rental amount (or profit in case of PLS arrangement) to buy the bank's stake in the property. The partnership will be terminated with the customer owning $100 \%$ of the project; the title will be transferred to him/her.

\section{Tawarruq}

Tawarruq is a financial instrument in which a buyer purchases a commodity from a seller on a deferred payment basis, and the buyer sells the same commodity to a third party on a spot payment basis (meaning that payment is made on the spot). It is the most popular product in Islamic banking sector especially in Middle East countries that been debated among Muslim Scholars. As they believe it has been contaminated by the current finance sector that taking advantage from Islamic concept to halal its transaction.

In Malaysia, Bank Islam Malaysia Berhad (BIMB) is using tawarruq mode for personal financing and home financing. Clearer picture of Tawarruq structure can be view later.

\section{Criteria Tawarruq}

Tawarruq can be defined as an act to buy the commodity by a person (mustawriq) on a deferred basis, and then sell it with a lower price on a cash basis to someone else other than the initial seller to acquire cash (Wizarah al-Awqaf wa al-Shu'un al-Islamiyyah, 1983). Contemporarily, the concept is used to underlie various Islamic banking products where the mustawriq is either the bank or the customer who desires cash, and the bank is always an agent (on behalf of the customer) to perform 
the sale or purchase transaction with a commodity broker (Mohamad, Rahman, 2014). Tawarruq consists of two sale and purchase contracts where the first involves the sale of an asset to a purchaser on a deferred basis and the subsequent sale involves sale of the asset to a third party on a cash basis as in Figure 3 (Property Financing-i (Tawarruq) Baiti Home Financing Version 3.0 June 2014).

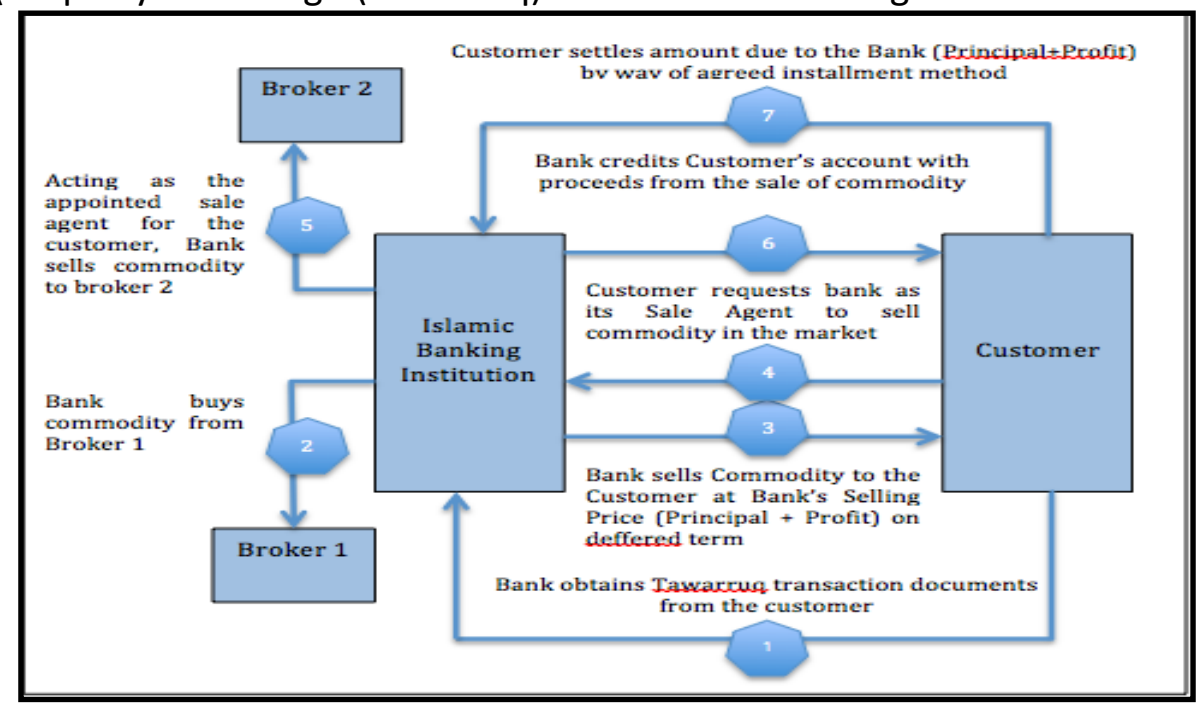

Figure 3: Sructure of Tawarruq house financing (Bank Islam Malaysia Berhad)

The Shariah concept applicable is Tawarruq. The structure and its mechanism are as follows:

1. Customer executes Sale \& Purchase Agreement (SPA) with Property Developer/ Vendor and becomes the owner of a property. In the event that SPA is not available, Letter of Intent may be used as a preliminary document.

For refinancing cases, the property may already be owned by the Customer (subject to structure executed with earlier financier).

2. Customer applies for financing with the Bank under the Shariah concept of Tawarruq for the purpose of settlement of the property purchased with Property Developer/Vendor (or existing financier).

For refinancing cases, the purpose of financing is to settle the existing financing with original financier.

Note: Later, the property will be charged to the Bank to secure the payment for the financing.

3. Upon receipt of Tawarruq transaction documents from the Customer, the Bank would purchase the commodity from Commodity Broker A.

Note : Tawarruq transaction documents include the following :

a. Appointment of the Bank as Sales Agent (ABSA)

b. Offer to Purchase (OTP) 
INTERNATIONAL JOURNAL OF ACADEMIC RESEARCH IN BUSINESS AND SOCIAL SCIENCES

Vol. 8, No. 12, Dec, 2018, E-ISSN: 2222-6990 C 2018 HRMARS

c. Tawarruq Master Facility Agreement (TMFA) iv. Tawarruq Agency Agreement (TAA)

4. The Bank then sells the commodity acquired to the Customer at Bank's Sale Price (Principal + Profit) on deferred payment basis.

5. Acting as a Sales Agent of the Customer, the Bank then sells the commodity to Commodity Broker $B$ on behalf of the Customer.

6. The proceeds from the sale of commodity are utilised for the settlement of the property purchased.

Note:

For refinancing cases, proceeds are paid directly to the existing financier and/or Customer.

7. Customer pays the Sale Price (Principal + Profit) of the commodity by way of an agreed deferred payment term.

\section{DISCUSSION}

The structure showed in each principle brings to a closer syariah guide but undeniable that it may contain the weakness and bring up the syariah issue among the Islamic practitioner. Conceptually it has been argued that house-financing concept based on $\mathrm{MM}$ is more superior to the BBA. The argument is based on the advantages of MM which is seen to promote the welfare of the people as the outstanding balance of financing at any point in time never exceed the original price of asset (Meera and Abdul Razak, 2005).

\section{CONCLUSION}

Referring to Islamic home financing concept, the structure should free from gharar (uncertainty) and make it clear for borrower, banking sector and seller. It has to simple it should be ensured that the transaction does not become a mere exchange of papers between two brokers, and one or two financial institutions. Shariah Board needs to strictly monitor all syariah principle's transaction based to avoid the existence of riba (usury) and Maisir (gamble). Islamic home financing must improve their products by adding the structure of takaful for the future innovation (Ghazali et al., 2017).

\section{REFERENCES}

Amin, H. (2008). Choice criteria for Islamic home financing. International Journal of Housing Markets and Analysis, 1(3), 256-274. doi:10.1108/17538270810895105 .

Aris, N. A., Othman, R., Azli, R. M., Arsyad, R., Sahri, M., \& Yaakub, A. R. (2012). Islamic house financing: Comparison between Bai' Bithamin Ajil (BBA) and Musharakah Mutanaqisah (MM). African Journal Of Business Management, 6(1), 266-273. doi:10.5897/ajbm11.2042.

Ayub, M. (2012). Use of W'ad and Tawarruq for Swaps in the framework of Islamic Finance. Retrieved from https://uaelaws.files.wordpress.com/2012/09/use-of-w-cc81ad-and-tawarruq-for-swaps-inthe-framework-of-islamic-finance-muhammad-ayub1.pdf.

Bahari, N. F., \& Baharudin, N. A. (2014). Kontrak Shariah Al-Tawarruq Konsep dan Aplikasinya dalam 
INTERNATIONAL JOURNAL OF ACADEMIC RESEARCH IN BUSINESS AND SOCIAL SCIENCES

Vol. 8, No. 12, Dec, 2018, E-ISSN: 2222-6990 @ 2018 HRMARS

Produk Perbankan $\quad$ Islam. $\quad$ Retrieved from http://www.kuis.edu.my/comm2014/eproceedings/C033.pdf.

Echchabi, A., \& Aziz, H. A. (2012). Shari'ah issues in Islamic banking: A qualitative survey in Malaysia. Retrieved from https://www.emeraldinsight.com/doi/pdfplus/10.1108/QRFM-12-2012-0035.

Ghazali, P. L., Mamat, M., Omar, L. B., Foziah, N. H., Guci, D. A., Abdullah, Y. B., \& Sazali E.N.S. (2017). Medical Integration Model Of Family Takaful For Blue Collar. Far East Journal of Mathematical Sciences (FJMS), 101(6), 1197-1205. doi:10.17654/ms101061197.

Lung, L. C. (2014). Musharakah Mutanaqisah Partnership in Malaysia Islamic Bank: A Comparison Between Theory and Practice. American Journal of Economics and Business Administration, 5(3), 95106. doi:10.3844/ajebasp.2013.95.106.

Meera, A. M., \& Razak, D. A. (2009). Home Financing through the Musharakah Mutanaqisah Contracts: Some Practical Issues. Journal of King Abdulaziz University-Islamic Economics, 22(1), 121143. doi:10.4197/islec.22-1.1.

Mohamad, N, Ab Rahman, A. (2014). Tawarruq application in Islamic banking: a review of the literature. Malaysia International Journal of Islamic and Middle Eastern Finance and Management Vol. 7 No. 4, 2014 pp. 485-501.

Razak, D. A., \& Taib, F. M. (2011). Consumers perception on Islamic home financing. Journal of Islamic Marketing, 2(2), 165-176. doi:10.1108/17590831111139875.

Saif al Nasser, S. A., \& Muhammed, J. (2013). Introduction to history of Islamic banking in Malaysia. Humanomics, 29(2), 80-87. doi:10.1108/08288661311319157.

Sairally, B. (2002). Murabahah financing: some controversial issues., Review of Islamic Economics, No. 12 , pp. $73-86$. 